\title{
CARNAVAL DE PERNAMBUCO: É SÓ CHEGAR? $O$ "NATIVO" E O “DE FORA" NO DISCURSO PUBLICITÁRIO DO GOVERNO DO ESTADO
}

\author{
André Luiz Maranhão de Souza Leão ${ }^{1}$ \\ Suélen Matozo Franco ${ }^{2}$ \\ Carlos Eduardo Polonio da Silva ${ }^{3}$
}

\section{Resumo}

O Carnaval de Pernambuco, além de representar um importante elemento da identidade local, contribui intensamente para a economia local. Dessa forma, o estado possui políticas públicas visando promover esses símbolos identitários e atrair cada vez mais investimentos. O presente estudo dedica-se às peças publicitárias desenvolvidas pelo Governo do Estado de Pernambuco para promover seu Carnaval. No intuito de compreender como esse governo mercadoriza o Carnaval pernambucano nessas campanhas, analisamos os vídeos veiculados entre os anos de 2002 e 2013, por meio da semiologia barthesiana. Tal procedimento nos levou à identificação de dez mitos, os quais interpretamos como constituintes de uma metanarrativa de trocas. Encontramos na teoria pós-colonial um esteio para a discussão dos achados. Nossa interpretação aponta para um patrimônio cultural reificado, uma visão de Pernambuco construída com base na alteridade, e portanto reforçadora de estereótipos, e uma orientação para a servilidade do Pernambucano, sob o álibi do discurso desenvolvimentista.

Palavras-chave: Carnaval; pós-colonialismo; semiologia barthesiana; mercadorização.

\section{CARNIVAL OF PERNAMBUCO: IS IT JUST GET THERE? THE “NATIVE" AND THE “OUTSIDER" ON THE STATE GOVERNMENT ADVERTISING DISCOURSE}

\footnotetext{
${ }^{1}$ Professor Adjunto do Departamento de Ciências Administrativas da Universidade Federal de Pernambuco. Email: aleao21@hotmail.com.

2 Doutoranda do Programa de Pós-Graduação em Administração da Universidade Federal de Pernambuco e professora substituta do Departamento de Ciências Administrativas da Universidade Federal de Pernambuco. E-mail: suelenmfranco@gmail.com.

${ }^{3}$ Mestre pelo Programa de Pós-Graduação em Administração da Universidade Federal de Pernambuco. Professor da Faculdade dos Guararapes e do Centro Universitário Maurício de Nassau. E-mail: caepolonio@gmail.com
} 


\begin{abstract}
The Carnival of Pernambuco, besides representing an important element of its local identity, contributes sorely to the local economy. Thus, the state has public policies aiming at promotion of such identity symbols and attract more investments. Present study dedicates to the advertisements developed by the Pernambuco State Government to promote its Carnival. In order to understand how this government commodifies the Carnival of Pernambuco in these campaigns, we analyzed the videos aired between the years 2002 and 2013 by Barthesian Semiology. This procedure resulted in the identification of ten myths, which we interpreted as constituents of an exchange metanarrative. We found in postcolonial theory a mainstay for discussing the findings. Our interpretation points to a reified cultural heritage, one Pernambuco vision built on otherness, and thus reinforcing stereotypes, e a guidance for the Pernambuco-born servility, under the development discourse alibi.
\end{abstract}

Keywords: Carnival; post-colonialism; Barthesian Semiology; commodification.

\title{
CARNAVAL DE PERNAMBUCO: SIMPLEMENTE LLEGAR? EL “NATIVO" Y LO “DE FUERA" EN LO DISCURSO PUBLICITARIO DEL GOBIERNO DEL ESTADO
}

\section{Resumen}

El Carnaval de Pernambuco, además de representar una parte importante de la identidad local, fuertemente contribuye a la economía local. Por lo tanto, el estado tiene políticas públicas para promover estos símbolos de identidad y atraer más investimentos. Este estudio está dedicado a las campañas publicitarias desarrolladas por el Gobierno del Estado de Pernambuco para promover su Carnaval. Con el fin de entender cómo este gobierno mercadoriza lo Carnaval de Pernambuco en estas campañas, analizamos los vídeos realizados entre los años 2002 y 2013, a través de la semiología barthesiana. Este procedimiento nos llevó a identificar diez mitos, que interpretamos como constituyentes de una meta narrativa de intercambio. Nos encontramos en la teoría poscolonial un pilar para la discusión de los resultados. Nuestra interpretación señala a un patrimonio cultural reificado, una visión de Pernambuco construida sobre la alteridad, y que por tanto refuerza estereotipos, e una orientación para el servilismo de lo pernambucano, bajo la coartada de lo discurso desarrollista.

Palabras-clave: Carnaval; poscolonialismo; semiología barthesiana; mercadorización. 


\section{iIntrodução}

Dentre as manifestações culturais de alto valor simbólico, encontra-se o Carnaval, marcado por uma busca pelo prazer e pela expressão (SILVA, 2005; DINIZ, 2008; DUMAZEDIER, 1994; MERQUIOR, 1972). No Brasil, o Carnaval é manifesto pela liberdade e irreverência e constitui uma das mais reconhecidas expressões da brasilidade (FERREIRA, 2004; DINIZ, 2008). Dentre as manifestações carnavalescas mais notáveis, encontram-se o Carnaval do Rio de Janeiro, cuja principal representação é o desfile das escolas de Samba na Marquês do Sapucaí, que atrai 4 milhões de pessoas; o Carnaval de Salvador, com seus trios elétricos e a axé music, que atrai 3 milhões de foliões anualmente; e o Carnaval de Pernambuco, que apresenta uma diversidade de manifestações e artefatos a 2,5 milhões de foliões (BRASIL, 2012; IG ECONOMIA, 2012; PERNAMBUCO, 2012B; RIOTUR, 2012; IG ECONOMIA, 2012; BRASIL, 2012; SETUR, 2012).

A diversidade e a irreverências são marcas do Carnaval de Pernambuco nacional e internacionalmente. Trata-se de um importante fenômeno social que manifesta as expressões culturais de um povo, constrói identidade e proporciona reflexões sobre a sociedade de diversas formas (ARAÚJO, 1997; DINIZ, 2008; PERNAMBUCO, 2011a): atrai um número significativo de pessoas às cidades no período festivo, movimentam produtores e expressões culturais, bem como recursos financeiros. Isso demonstra tanto sua relevância sociocultural (DINIZ, 2008), na medida em que constitui um dos maiores festejos de rua do País, quanto contribui para a economia local. Os recursos oriundos dos produtos ofertados por ocasião das festividades superaram meio bilhão de reais em 2012 (SETUR, 2012) e 19 cidades são impactadas diretamente pelo evento, recebendo um número considerável de visitantes e ampliando o transporte e o abastecimento, bem como praticamente esgotando a capacidade da rede hoteleira e dos restaurantes (Tendências e Mercados, 2011).

Nesse sentido, desde o século passado o Carnaval passa a ser alvo tanto de políticas públicas quanto de iniciativas do setor privado no sentido de gerir o evento e dele extrair retornos, sobretudo, de natureza econômica. Com isso, o festejo converte-se num espetáculo para apreciação daqueles que vêm de fora (MEDEIROS, 2003), num processo de mercadorização dessa cultura. Cabe questionar se esse processo não ocasionaria uma inversão de valores, em que a mercadorização define as diretrizes da manifestação cultural, sendo esta ressignificada e tendo seus elementos alterados de forma a adaptar-se à lógica capitalista.

O presente trabalho dedica-se ao estudo das peças publicitárias do Carnaval de Pernambuco promovidas pelo Governo do Estado. Escolhemos esse agente devido ao seu papel na preservação da cultura popular. Na medida em que esse representante do Poder Público converte 
uma manifestação cultural e um conjunto de símbolos identitários em mercadoria e destino turístico, formulamos o seguinte questionamento: Como o Governo do Estado de Pernambuco mercadoriza o Carnaval pernambucano em suas peças publicitárias?

As manifestações da cultura popular têm sido reconhecidas, no plano político, como potenciais instrumentos para sanar problemas tanto de ordem social quanto econômica (YUDICE, 2006), o que se materializa em ações da Administração Pública (bem como outras esferas interessadas) no sentido de aproveitar esse potencial. Nesse sentido, as manifestações obtêm não só legitimidade, mas também incentivo do Poder Público. No presente estudo, esse incentivo está fortemente vinculado a interesses econômicos, com destaque para o fortalecimento do turismo no Estado e a geração de renda advinda dessas atividades. O estudo ora proposto justifica-se pela necessidade de compreender como se dá essa intervenção da Administração Pública nos festejos carnavalescos, bem como quais os impactos dessa intervenção nos significados criados ao longo dos anos por essas manifestações. Partimos de uma discussão acerca do festejo carnavalesco, seguida dos procedimentos método-analíticos, para apresentarmos nossos achados e interpretarmos à luz da teoria encontrada. Por fim, tecemos as considerações finais.

\section{“Um Carnaval que 'vale' por muitos"}

As origens do festejo carnavalesco estão longe de ser unanimidade. No entanto, todas as versões guardam um elemento em comum: a inversão da ordem no cotidiano (LOSSIO; PEREIRA, 2008; SEBE, 1986). A despeito das versões, sua origem costuma ser atribuída à Europa. Como exemplo, podemos citar cultos à fertilidade, ligados aos ciclos anuais de plantações; as bacanais, lupercais e saturnais, em que os excessos (sexuais, alcoólicos, alimentícios) eram permitidos, num período em que a inversão de valores era essencial (SEBE, 1986).

Um aspecto inerente aos festejos carnavalescos é a tensão entre o público e o privado, que permeia toda a história dos festejos carnavalescos desde suas raízes europeias. Segundo Sebe (1986, p.34), “desde sempre o Carnaval manteve a ideia de espaços como fundamental: os salões para a elite; a rua para o grande público, pobre". Às ruas, cabiam os jogos de entrudo, de inspiração lusitana, violentos, nos quais se arremessavam contra os participantes e transeuntes farinha, água, goma, fuligem (LOSSIO; PEREIRA, 2008; SEBE, 1986; ARAÚJO, 1997). Por outro lado, sob a inspiração veneziana, os salões eram povoados de máscaras e fantasias luxuosas (SEBE, 1986; ARAÚJO, 1997).

O Carnaval de rua, que hoje se acredita ser a feição do Carnaval brasileiro, tem uma história de luta, mas também de convergência de interesses. De acordo com Araújo (1997), como era por meio das celebrações públicas que a sociedade tentava representar a si mesma, as 
elites tentaram substituir o entrudo pelos festejos inspirados nos salões europeus. As ruas então passam a receber cortejos, com carros alegóricos ricamente adornados, nos quais as elites desfilavam, cabendo ao povo o papel de espectador. Nesse estilo de festa exigente, tinham destaque os clubes de alegoria e crítica, que demandavam não só o capital econômico como também capital cultural. Tendo sua mobilidade no espaço público restrita ou até negada, as camadas mais populares começam a materializar sua resistência, a exemplo dos clubes pedestres, cujos nomes, muitas vezes, eram alusivos às categorias profissionais. Tais clubes retomavam uma noção antiga de Carnaval e, se não eram proibidos por lei, sofriam séria desaprovação pelas elites e autoridades, postura que muda no início do século XX, quando as autoridades passam a reconhecer tais agremiações, bem como seu potencial de disciplinar o trabalhador.

O declínio dos clubes de alegoria e crítica revelam, ainda segundo Araújo (1997), uma derrota do plano político-ideológico do Carnaval das máscaras e críticas, o Carnaval elitizado que surgira entre os séculos XIX e $X X$, condenando a prática "nefasta" do entrudo, numa tentativa de impor um festejo para qual se exigia um capital econômico e intelectual indisponível à maior parte da população. O reconhecimento do Carnaval popular, ainda que outrora símbolo da derrota político-ideológica, passou a despontar como uma oportunidade tanto para o Poder Público quanto para o setor privado. Num movimento inverso à negação e ao combate, segundo Medeiros (2003), o Poder Público passa a ver nos folguedos um espetáculo digno de ser apreciado, e portanto vendido, àqueles que vêm de fora. Nesse sentido, tais manifestações são elevadas ao status de símbolos identitários, geridas sob o rótulo de cultura popular. Ainda segundo o autor, a indústria cultural adere a essa onda de reconhecimento oficial, no intuito de obter retorno financeiro oriundo do aumento de fluxo de participantes nesses folguedos.

O carnaval, enquanto festa pública forneceu os ingredientes necessários à construção da identidade pernambucana calcada no binômio do nacional-popular (ARAÚJO, 1997). Desde o sábado de Zé Pereira, quando os clarins de Momo anunciam o festejo, os foliões fantasiadas e mascaradas invadem as ruas das principais cidades. $\mathrm{O}$ povo se organiza em blocos, troças, clubes, caboclinhos, maracatus, ursos. Assim como há uma multiplicidade de agremiações, o mesmo ocorre com os ritmos tocados e dançados durante o festejo. Como um arlequim criativo e multifacetado, o carnaval pernambucano encanta por sua originalidade numa síntese de ritmos e culturas (PERNAMBUCO, 2011A; CARVALHO, 2007).

O Carnaval é a festa que movimenta a economia; os números do festejo em 2011 revelam o impacto que a Folia de Momo proporcionou à economia de Pernambuco: a receita deixada pelos visitantes foi de R\$ 570 milhões, um aumento de $54 \%$ em relação ao Carnaval do ano anterior, que gerou uma receita de $\mathrm{R} \$ 370$ milhões; o Estado recebeu cerca de um 
milhão de visitantes, um crescimento de $28,67 \%$ comparado ao público de 2010, quando 800 mil pessoas visitaram Pernambuco durante o carnaval; e a maioria dos foliões ficou hospedada na Região Metropolitana do Recife, que registrou 96\% de ocupação hoteleira (TENDÊNCIAS E MERCADOS, 2011).

Os resultados positivos também foram registrados em todas as 19 cidades polo, do Litoral ao Sertão. A média estadual de ocupação hoteleira foi de 90\%, com destaque para Águas Belas, Bezerros, Nazaré da Mata e Vitória de Santo Antão, que registraram 100\% de ocupação. O Gasto Médio Individual Diário (GMID) no Estado foi de $\mathrm{R} \$ 133,00$. Vale ressaltar que os turistas hospedados em hotel tiveram um Gmid superior, na casa dos R\$267,68. A permanência média foi de nove dias (TENDÊNCIAS E MERCADOS, 2011).

Os números do Carnaval 2011 foram levantados pela Empresa de Turismo de Pernambuco (Empetur), através da Unidade de Gestão da Informação, que realizou uma pesquisa entre os dias 09 e 13 de março, no Aeroporto do Recife, Terminal Integrado de Passageiros (TIP), em algumas cidades-polos e nos postos da Polícia Rodoviária nas rodovias BR 232, BR 101-Norte, BR 101-Sul e PE 060. Além da pesquisa presencial, a Empetur também fez um levantamento em toda a rede hoteleira pernambucana pelo telefone. A metodologia utilizada pela Empetur é aceita pela Organização Mundial do Turismo (OMT) e leva em consideração os dados coletados nas duas sondagens para projetar os números globais (Tendências e Mercados, 2011).

Além do Recife e Olinda, o carnaval pernambucano é composto por polos em outros dezessete municípios, são eles: Águas Belas, Belém de São Francisco, Bezerros, Catende, Goiana, Ipojuca, Itamaracá, Jaboatão dos Guararapes, Nazaré da Mata, Paudalho, Pesqueira, Petrolina, Salgueiro, Tamandaré, Timbaúba, Triunfo e Vitória de Santo Antão (PERNAMBUCO, 2011a).

Em Águas Belas, tem o samba de coco e as danças dos índios da tribo Fulni-ô que fazem a animação. O Berrador, O Zumbi e O Beija-Flor (blocos formados pelos índios) são as agremiações mais conhecidas. Já em Belém de São Francisco o desfile dos primeiros bonecos gigantes do Brasil, a tradição é mantida pelos sertanejos que saem atrás dos cabeçudos na terça-feira gorda (PERNAMBUCO, 2011B; FUNDARPE, 2011).

A Terra dos Papangus é Bezerros, cidade que tem uma cultura que vai além dos mascarados. O carnaval do município é o maior do agreste pernambucano e o único temático do interior do Brasil. Catende é, talvez, a cidade que tenha o único bloco carnavalesco que sai da porta de um cemitério. A mulher da sombrinha é uma boneca gigante que percorre as ruas da cidade arrastando a multidão. Em Goiana, os tradicionais caboclinhos desfilam pelas ruas da cidade estalando as preacas, ao som dos pífanos (PERNAMBUCO, 2011b). 
Em Ipojuca, Itamaracá, Tamandaré, Timbaúba e Jaboatão dos Guararapes muitos blocos desfilam por estas cidades garantindo animação aos foliões da cidade. Nazaré da Mata, na segunda feira de carnaval, é marcada pelo encontro de mais de cem nações de Maracatu para um desfile que atrai gente do mundo inteiro (PERNAMBUCO, 2011b).

Paudalho é lugar dos ursos, bois, caboclinhos, maracatus e outros tantos personagens do Carnaval pernambucano que se encontram para dezenas de apresentações do que há de melhor em Pernambuco. Pesqueira, terra dos índios Xucurus, mantém a tradição dos caiporas, personagens mascarados que desfilam no domingo de carnaval (PERNAMBUCO, 2011b).

Petrolina é a terra das carrancas do Estado, e o carnaval da cidade é animado por blocos e troças que arrastam os foliões. Em Salgueiro, temos a bicharada do mestre Jaime, bloco carnavalesco que atrai gente de toda a região. Além do bloco, Salgueiro conta com influências dos batuques africanos; na cidade, encontra-se a importante comunidade quilombola Conceição das Crioulas (PERNAMBUCO, 2011b).

Triunfo é a cidade dos Caretas, mascarados que desfilam pelas ruas com um imenso chicote chamado de relho. O estalar dos relhos é um dos mais originais folguedos do carnaval pernambucano. Já em Vitória de Santo Antão, a disputa é pela escolha do melhor bloco. Camelo, Leão e Girafa são os mais conhecidos. E a batalha com confetes e serpentinas é pela preferência dos foliões (PERNAMBUCO, 2011b).

Toda essa diversidade de manifestações é fruto de um processo no qual os grupos lutam para produzir significações, inseridos num contexto sócio-histórico. Logo, os elementos do Carnaval Pernambucano não são criações desistoricizadas e cuja significação é dada a priori, mas resultado de uma construção dada num longo processo de lutas e elaboração identitária. A despeito dessas lutas para gerar significações nas culturas, o mercado desponta como o único lócus de legitimação na sociedade pósmoderna, na qual tudo parece converter-se em mercadoria (FIRAT; DHOLAKIA, 2003). Assim, as manifestações populares, tais como festas, danças, artes, culinária, deixam de pertencer a seus protagonistas para se converter num objeto de troca, tornando-se espetáculos, inseridos num circuito de eventos cosmopolitas, cuja tônica é a prestação de serviços de entretenimento e turismo, com base em redes midiáticas que veiculam símbolos e mercadorias (FARIAS, 2005; MONTES, 1998).

É nesse contexto que se insere o Carnaval pernambucano. Assim, essa dimensão econômica alinha-se aos interesses tanto de instituições do Poder Público quanto empresas, do âmbito privado, que têm, nos profissionais de marketing e nos meios de comunicação, a concretização desses interesses.

\section{A semiologia barthesiana}


A Semiologia foi apontada pelo linguista francês Ferdinand de Saussure como a Ciência Geral dos Signos, em sua obra Curso de Linguística Geral, de 1916 (HÉNAULT, 2006). Ela se ocupa do universo de sons, imagens, gestos, objetos e ritos. A despeito do avanço dos estudos de Linguística, a Semiologia restringiu-se ao estudo de códigos rodoviários, até que os estudos de Saussure despertaram nos outros pesquisadores a compreensão da sua profundidade sociológica, incorporando-se novas possibilidades a essa área do conhecimento (BARTHES, 2006). Entre os pesquisadores que se sensibilizaram para esse potencial, Roland Barthes, igualmente linguista, ao estudar a obra basilar de Saussure, viu além das estruturas dos códigos linguísticos; dessa forma, passou a dedicar-se principalmente ao entendimento da construção dos sistemas de significados, bem como os discursos que ocasionam a espetacularização do cotidiano (ROCHA, 2005; BARKER, 2012).

As noções iniciais de semiologia propostas por Saussure, situando-a entre os elementos de língua e fala, serviram de aporte aos estudos dos processos de significação elaborados por Roland Barthes; tais noções assumem que o sistema de significação é formado por um conjunto de signos, e estes são constituídos por significantes e significados, elementos que possibilitam sua análise (BARKER, 2012; RAMOS, 2001).

Toda semiologia, enquanto ciência das formas, propõe uma relação entre esses dois termos (significante e significado), cujo total associativo corresponde ao signo (BARTHES, 2010). O significante medeia o processo de significação, necessitando da matéria, uma vez que a substância da expressão, no sistema semiológico, é material. Já o significado corresponde à representação psíquica das coisas, o que entendemos por elas (BARTHES, 2006).

O primeiro encontra-se no plano da expressão, e o segundo, no do conteúdo. Cada plano comporta uma forma, passível de descrição detalhada, simples e coerente pela linguística, e a substância, fenômenos linguísticos cujo estudo requer premissas de ordem extralinguística (BARTHES, 2006). Sendo assim, significante e significado unem-se, num processo de significação, resultando num signo (RAMOS, 2008).

Para Roland Barthes, no entanto, esse processo se refere apenas a um primeiro sistema semiológico e propõe um segundo, que baseado no primeiro, evidencia mitos.

$\mathrm{O}$ autor define o primeiro como linguagem-objeto, pela sua natureza linguística; o segundo - denominado por Barthes metalinguagem, ou seja, uma língua que se refere a outra, por ser construído com base no primeiro -, é o próprio mito (BARTHES, 2010; SIMÕES, 2006). Em outras palavras, é com base numa cadeia semiológica que um sistema particular, portanto um segundo sistema semiológico, pode ser construído. Isso se dá como se o mito fosse deslocado de um nível: o sistema formal das primeiras significações (BARTHES, 2010; BARKER, 2012). Essa construção é esquematizada na Figura 1. 
Figura 1 - Representação Metafórica da Construção do Mito

Língua $\left\{\begin{array}{|c|c|c|}\begin{array}{c}1 . \\ \text { Significante }\end{array} & \text { 2. Significado } \\ \begin{array}{c}\text { 3. Signo (sentido) } \\ \text { I - SIGNIFICANTE (forma) }\end{array} & \begin{array}{c}\text { II - SIGNIFICADO } \\ \text { (conceito) }\end{array} \\ & \text { Fonte: Adaptado de Barthes (2010) e Souza e Leão (2013) }\end{array}\right\}$ MITO

O mito é um sistema de comunicação, uma mensagem, um modo de significação, uma forma. Na medida em que todo mito é fala, tudo é passível de constituir um mito, e este é alicerçado na conotação (RAMOS, 2008). No entanto, é uma fala inocente, embora suas intenções não sejam escondidas, mas naturalizadas. Assim, a leitura que se faz de um mito é como sistema de fatos, quando, na verdade, trata-se de um sistema semiológico. Dessa forma, a fala sofreu um processo de naturalização de forma a torna-se inocente; como resultado, o leitor não enxerga o sistema semiológico, cuja existência, muitas vezes, ele desconhece (BARTHES, 2010; RAMOS, 2001; BARKER, 2012).

Isso proporciona uma espécie de imersão numa ideologia anônima, construída pela sociedade, e na qual ela própria relaciona-se de forma pacífica com formas que não são precisamente ideológicas nem políticas, porém naturalizadas, na medida em que a realidade se converte em imagem do mundo, e a história, em natureza (BARTHES, 2010; DANESI, 2010; CHANDLER, 1999).

Para Barthes (2010), essa constante solicitação, ou melhor, exigência inflexível de que os homens se reconheçam nessa imagem deles próprios, como se sempre tivesse sido assim, constitui a essência dos mitos.

\section{Procedimentos metodológicos}

A presente investigação é de natureza qualitativa, na qual o pesquisador elabora os padrões, categorias e temas no estudo de determinado fenômeno, por meio de lentes teóricas (CRESWELL, 2010), e apresenta orientação crítica não performativa, pautada pela desnaturalização e reflexividade (DENZIN; LINCOLN, 2006) perante o fenômeno. É uma pesquisa de caráter indutivo, na medida em que não parte de categorias analíticas a priori, embora a indução possa ocorrer em diversos graus na pesquisa qualitativa (LEÃO; MELLO; VIEIRA, 2009). No presente estudo, partimos da semiologia barthesiana para analisar os dados, que só então apontaram para um aporte teórico. O paradigma 
semiótico constitui um dos mais antigos e profícuos no estudo dos processos de produção de significados (OSWALD; MICK, 2006).

A constituição do corpus deu-se pela coleta de dados documentais, a saber: filmes publicitários do Governo do Estado de Pernambuco para promover o Carnaval pernambucano, produzidos entre os anos de 2002 e 2013, cedidos pelas agências Gruponove Comunicação (2002 a 2005) e Arcos Comunicação (2010 a 2012) ou disponíveis nos websites YouTube (2006 a 2008) e Empresa Pernambucana de Turismo (Empetur) (2013). Em alguns anos, a campanha foi composta de apenas um filme; em outros, a campanha constituiu-se de uma série de filmes.

O corpus sofreu uma ruptura no intervalo de tempo, uma vez que a agência responsável não localizou o material referente à campanha de 2003 (mas apenas as campanhas pós-carnaval, conforme identificado pelos pesquisadores durante a análise), e o ano de 2007 foi marcado por uma transição de gestão estadual, incorrendo na ausência de um contrato de prestação de serviços publicitários à época, conforme informações do Núcleo Estratégico de Comunicação do Governo de Pernambuco.

Os títulos das campanhas, bem como seus respectivos anos de veiculação, são: O carnaval de Pernambuco é mais pra você (2002); Pernambuco dos melhores carnavais (2004); Pernambuco é o seu carnaval, é a sua praia (2005); O melhor carnaval fica na terra das melhores praias (2006); Carnaval de Pernambuco é só chegar (2008); As muitas caras de um carnaval de todos (2009); Pernambuco - um carnaval que vale por muitos (2010 e 2011); Pernambuco - um estado de alegria (2012) e Pernambuco estado de alegria (2013).

A opção por vídeos, e não outros formatos de peça publicitária, justifica-se pela problemática, na medida em que fatos reais podem ser registrados temporalmente por meio dos recursos fílmicos, bem como levou-se em consideração a influência que os meios de comunicação exercem sobre a sociedade (LOIZOS, 2002).

Os vídeos foram recortados em cenas que constituíam unidades de sentido, depois de assistido diversas vezes pelos pesquisadores, resultando em trezentas e noventa e seis (396) cenas submetidas à análise semiológica barthesiana. Para ilustrar, na Figura 2, temos a interseção entre cenas da campanha de 2011 (v13): à esquerda, um grupo de foliões festeja o Carnaval de Olinda e, ao lado direito, o folião encontra-se no Marco Zero ao término da festa. A elaboração das cenas levou em consideração um conjunto de elementos composto de textos, narrativas, som e imagem; cada uma foi cronometrada e codificada de modo a possibilitar a localização no processo de análise e validação pelos pesquisadores. Assim, utilizamos a letra "v" e a numeração correspondente à posição do vídeo na ordem cronológica das campanhas; o mesmo critério foi adotado para as cenas, utilizando-se a letra " $c$ ": assim, quando identificamos v13c5, referimo-nos à cena 5 do vídeo 13, veiculado no ano de 2011. 
Figura 2 - Interseção de cenas numa campanha

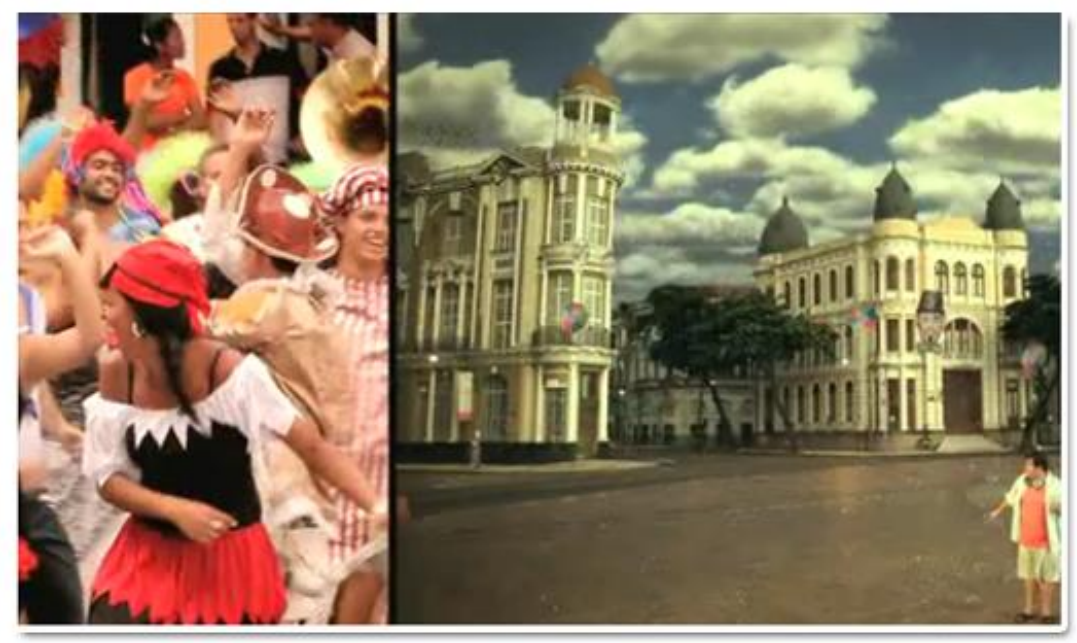

Em consonância com o procedimento analítico adotado, a análise dos dados foi realizada em duas etapas: a análise linguística constitui a primeira, quando os elementos textuais e audiovisuais que permitiram a identificação de significantes foram identificados e descritos em cada vídeo, assim como seus significados e os signos gerados no primeiro sistema semiológico; já na segunda etapa, obtido o primeiro sistema, os signos deste foram considerados significantes do segundo sistema, levando aos significados e à elaboração de mitos, conforme abordado na seção anterior. Este segundo momento constitui, pois, não só um procedimento analítico, como também a lente teórica que conduziu a investigação a priori. Inspirados no trabalho de Souza e Leão (2013), articulamos, a partir dos mitos identificados na análise, uma metanarrativa mítica, que serviu de base para a interpretação dos achados à luz de uma teoria social específica.

Em cada etapa, houve a apreciação por um par de pesquisadores, consistindo num processo de triangulação, permitindo a validação da análise. Os achados eram submetidos ao pesquisador sênior, para validação final e elaboração de insights, ensejando a reflexividade do procedimento analítico. Por fim, realizou-se uma descrição densa e detalhada dos resultados, de forma a tornar a inferência analítica inteligível aos leitores. Tais procedimentos atendem a critérios de qualidade da pesquisa qualitativa (PAIVA JUNIOR; LEÃO; MELLO, 2011).

\section{"Carnaval de Pernambuco: é só chegar"}

Em virtude do espaço, não apresentaremos a descrição analítica de cada mito identificado. Utilizaremos um exemplo para ilustrar como procedemos à análise em todo o corpus. Dessa forma, demonstramos as 
etapas de análise que culminaram com a identificação de um dos mitos. A Figura 3 se refere às cenas 6 e 12, dos vídeos 14 e 15, respectivamente, recortadas da campanha 2011. Nela, eliciamos como significante homens carregando um folião turista numa liteira, que, do alto desta, acima da multidão, acena com um chapéu para todos. No frame, o protagonista da festa é o turista, que demonstra encantamento enquanto os demais foliões demonstram familiaridade com o festejo apresentado. Esse turista é colocado, sob o consentimento dos demais foliões, numa posição de destaque, ao qual os foliões rendem as reverências e a hospitalidade. Inferimos desses elementos o significado NATIVO. Esse nativo ocupa uma postura de subserviência, na qual não se porta propriamente como um folião - na medida em que, como folião, estaria a se deleitar tanto quanto o turista, e não a servi-lo - , mas como o ofertante de um momento de diversão para o turista, no qual renuncia seu status de folião para servir ao "cliente", convertendo o festejo carnavalesco num serviço e o turista num cliente.

$\mathrm{Na}$ análise da relação entre significante e significado, inferimos a produção do signo SERVILISMO, que é incorporado como forma de segunda ordem, cujo significado remonta ao conceito CLIENTISMO, nos levando à elaboração do mito CLIENTE-REI.

Com base no procedimento exemplificado, estabelecemos as relações sintagmáticas entre significantes e significados, gerando os signos do sistema primeiro e, a partir desses, suas relações com os conceitos, culminando com os mitos. Na sequência, passamos a essas relações, sempre a partir dos 12 mitos eliciados, procedimento no qual também descrevemos cada categoria empírica. De forma a favorecer a compreensão destas categorias, sempre que são chamadas em sua definição aparecem com os seguintes recursos visuais: os termos referentes aos mitos estão negritados; os que se referem aos signos, sublinhados; por fim, com sublinhado duplo encontram-se os termos relativos aos conceitos. 
Figura 3 - Exemplo da análise semiológica

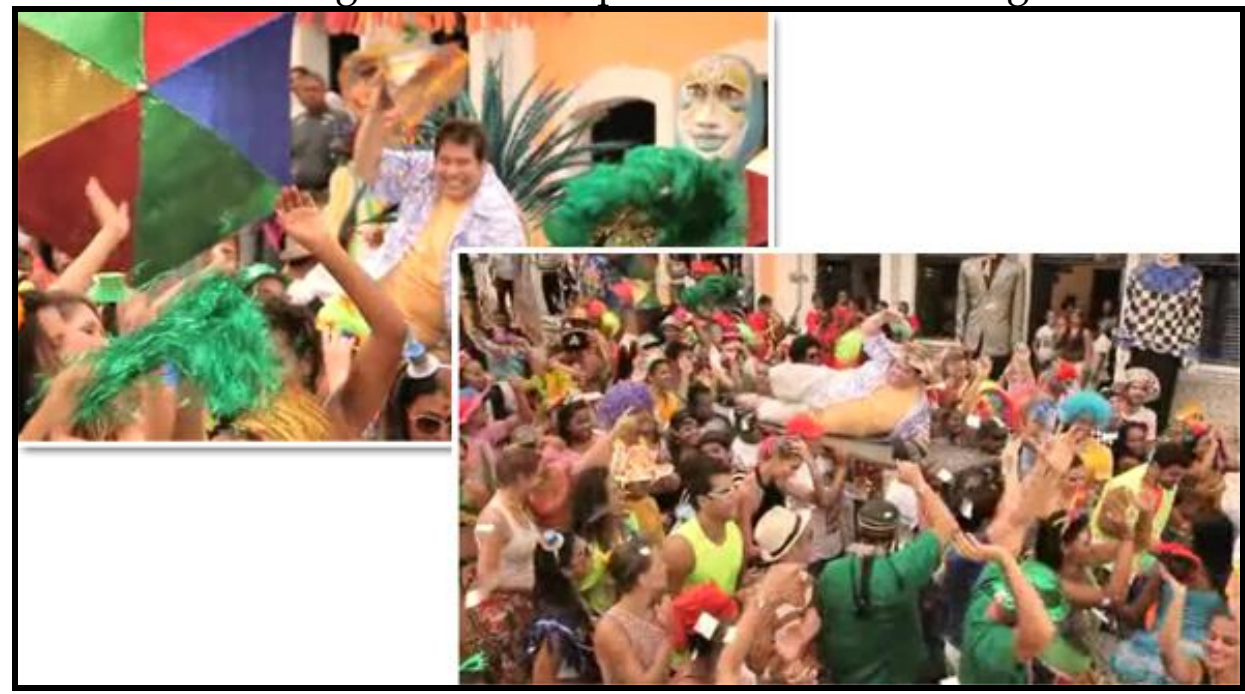

O mito alegria se refere ao estado de regozijo propiciados pela fruição da festa de momo. Este mito revela-se nas relações de cinco signos com o conceito deleite, que se refere à entrega ao prazer que o carnaval propicia. Esses signos são (vide Figura 4): ansiedade [A], dedicação [B], diversão [C], estranhamento [D] e frenesi [E].

O signo ansiedade remete ao conceito deleite por evocar uma disposição de inquietude e expectativa em relação à fruição que se aproxima. Na imagem da Fig. 4A, a expressão facial e o gesto com o braço do folião, interpretado pelo ator Selton Mello, demonstram esse estado emocional.

O signo dedicação, por outro lado, evoca o conceito deleite em situações em que o folião demonstra prazer ao direcionar energia, empenho e talento na elaboração dos elementos da festa carnavalesca. $\mathrm{Na}$ imagem da Fig. 4B, o homem mostra envolvimento e satisfação ao confeccionar a indumentária a ser utilizada no festejo carnavalesco.

O signo diversão, por sua vez, remete ao conceito deleite a partir do envolvimento do folião com o clima de entretenimento que o festejo proporciona. Na imagem da Fig. 4C, o folião encontra-se envolto na atmosfera de divertimento do Carnaval.

O signo estranhamento remete ao deleite na medida em que o foliãoturista dissolve, por meio da entrega à folia, sua incompreensão de algumas manifestações culturais. Na imagem da Fig. 4D, o folião deparase com manifestações culturais que desconhece, o que gera uma sensação de estranhamento, mas esta logo se dilui uma vez que ele quer usufruir todos os prazeres do Carnaval, independentemente de ver sentido em seus elementos.

Por fim, o signo frenesi remete ao conceito deleite na medida em que o folião entrega-se completamente ao êxtase do Carnaval. Na imagem da 
Fig. 4E, há um grupo de foliões completamente envolvidos no festejo carnavalesco, como se estivessem vivenciando um transe coletivo.

Figura 4 - O mito alegria

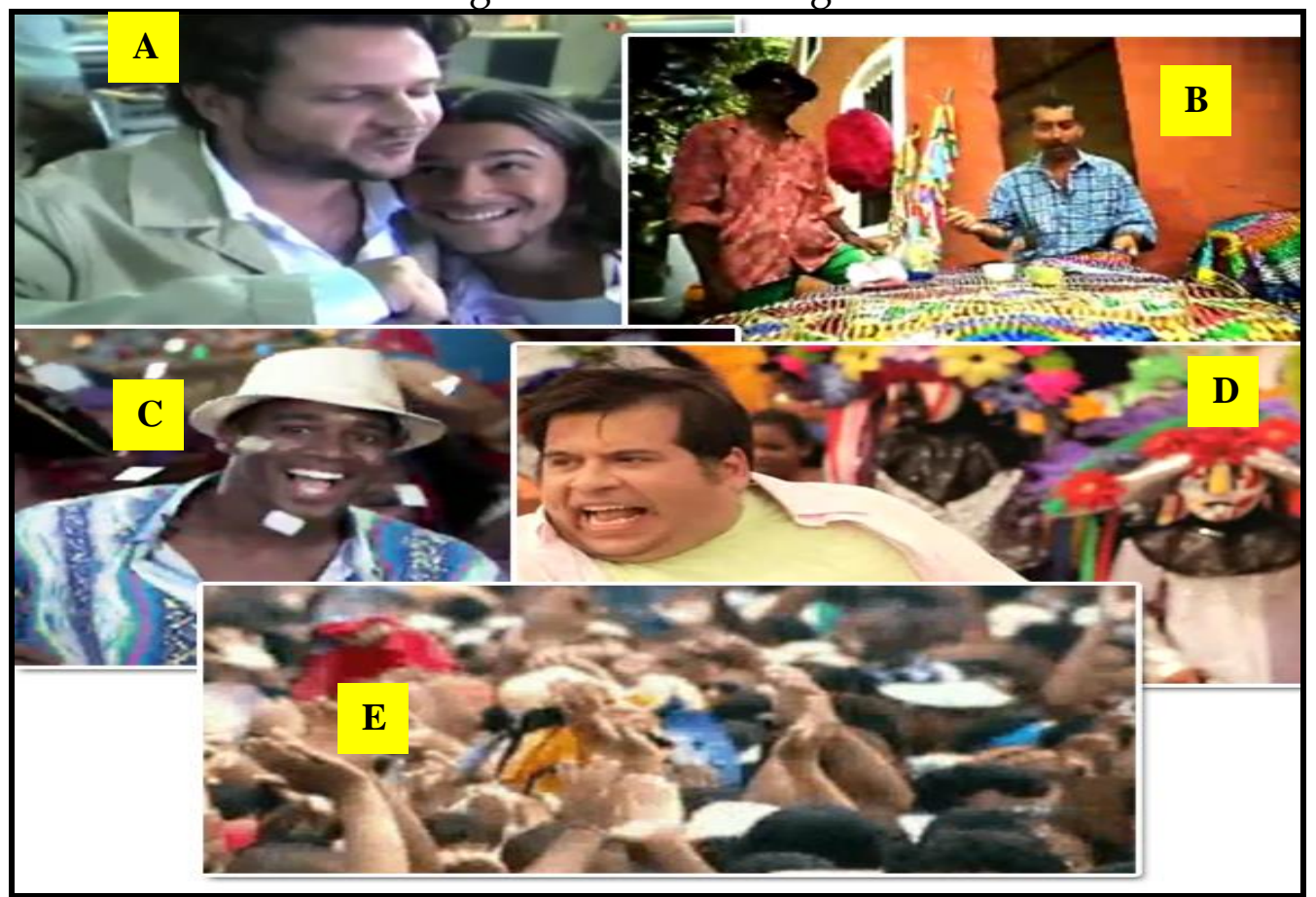

O mito liberdade se refere à sensação de ausência de cerceamento social, psicológico ou moral, na qual o indivíduo pode vivenciar quaisquer experiências que desejar. Advém da relação entre o signo segredo e o conceito deleite, já apresentado quando da exposição do mito alegria, uma vez que ele é base também daquele. O signo segredo, por sua vez, se refere ao comportamento do folião de se ocultar para não ser descoberto. $\mathrm{Na}$ imagem da Fig. 5, os foliões têm sua face velada, e com isso sua identidade preservada, permitindo-lhes aproveitar das brincadeiras sem restrições, convenções ou imposições e dançar e brincar de qualquer maneira, sem que se lhe permita tolher.

Figura 5 - O mito liberdade

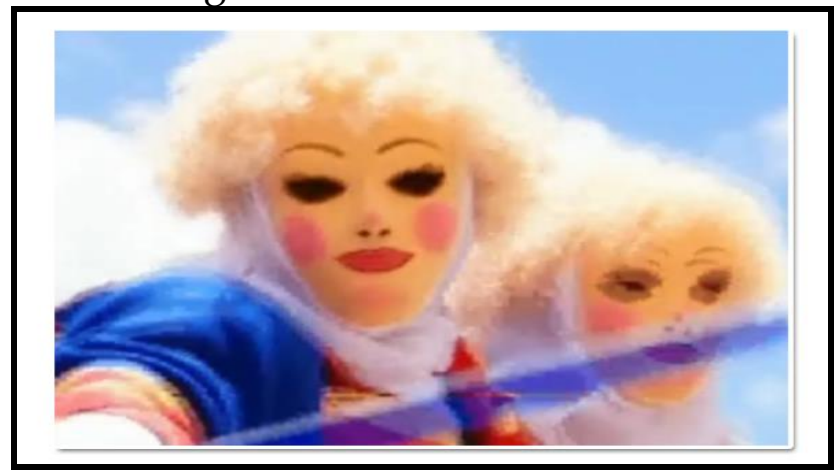


O mito cliente-rei se refere à concessão de atenções exclusivas ao folião-turista, pronto atendimento dos seus interesses; reverência ao indivíduo "de fora", considerado o mais importante. Decorre das relações dos signos (vide Figura 6) empoderamento [A] e servilismo [B] com o conceito clientismo, que alude à dispensa de todas as atenções necessárias ao usuário de um serviço, no caso, o tratamento do folião-turista como consumidor de serviços.

O signo empoderamento se refere ao poder de escolha do foliãoturista sobre como usufruir da manifestação cultural, por meio de um conjunto de solicitudes dispensadas a este sujeito "de fora". Na Fig. 6A, ao folião-turista, representado pelo ator Leandro Hassum, é atribuído o status de centro das atenções, para o qual os demais foliões (nativos) voltam-se no intuito de oferecer o Carnaval como um festejo elaborado para o prazer dele, configurando-se uma relação ofertante-cliente, em que o turista figura como beneficiário (cliente) dessa troca.

Por servilismo nos referimos condição submissa de atender aos desejos e caprichos do folião-turista que vem em busca do Carnaval de Pernambuco. Na Fig. 6B, um nativo aparece em posição de servilidade, como se estivesse a oferecer o melhor que o Estado possui a quem vem de fora.

Figura 6 - O mito cliente-rei

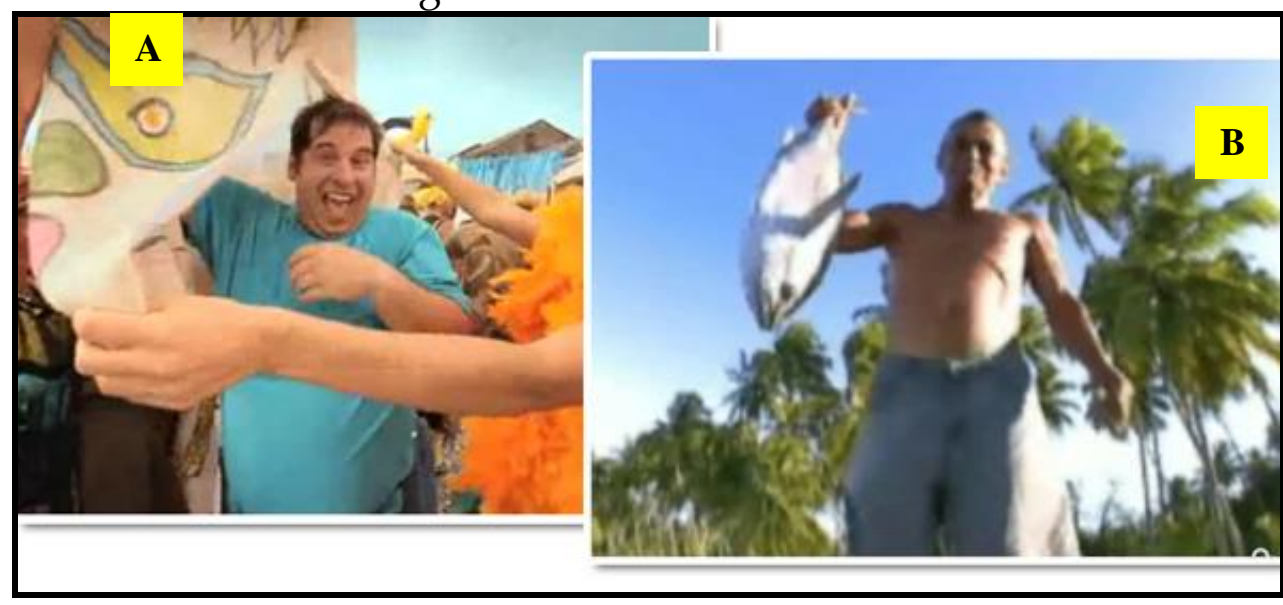

O mito assenhoreação revela o intuito de se apropriar da manifestação cultural e dos seus elementos, desconsiderando o contexto social, histórico, político e cultural em que eles se inserem. Sustenta-se na relação entre o signo usurpação e o conceito reificação. Por reificação nos referimos à conversão das manifestações do Carnaval em objetos consumíveis, desconsiderando os aspectos culturais e históricos, importância social e riqueza artística. Usurpação, por sua vez, aponta para a extração do melhor que a manifestação pode oferecer, sem que haja envolvimento ou contrapartida. $\mathrm{Na}$ figura 7A, o folião-turista, 
interpretado pelo ator Marcelo Adnet, beija um boneco gigante de Belém do São Francisco, sem se ater ao papel que esse elemento possui na cultura pernambucana e na arte bonequeira, nem à tradição de desfilar bonecos gigantes no Carnaval pernambucano, bem como o que esses bonecos representam para as populações locais.

Figura 7 - O mito assenhoreação

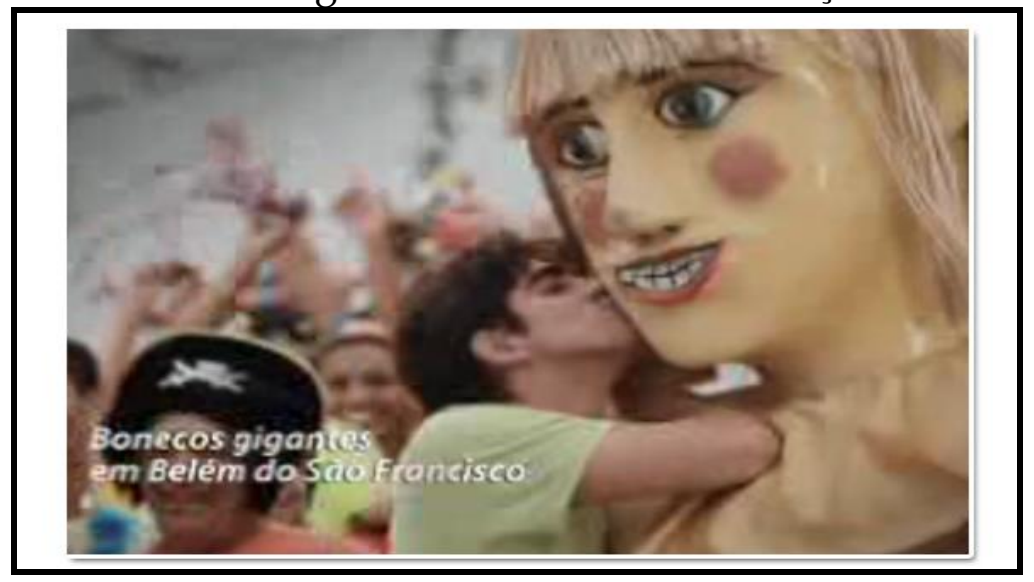

O mito contemplação remete ao apelo que as imagens do ambiente natural de Pernambuco geram no espectador convidando ao aprazimento e ao descanso. Alicerça-se no conceito esplendor, que se refere ao deslumbramento que a observação do ambiente natural pode gerar no expectador. Tal conceito, por sua vez, relaciona-se a três signos: natureza que apresenta as paisagens naturais do inalteradas; pureza, que atesta a virtude das paisagens naturais por meio da limpidez das águas, do ar e das praias; e segurança, relativa à proteção advinda de ambientes naturais ausentes de perigo. Em virtude da aproximação de tais signos, uma mesma imagem é reveladora dessas relações. Na Fig. 8, uma imagem contemplativa de uma praia em Fernando de Noronha apresenta um mar de águas calmas, praia deserta, com águas claras e puras e predomínio de elementos naturais, onde podem ver vistas poucas embarcações.

Figura 8 - O mito contemplação

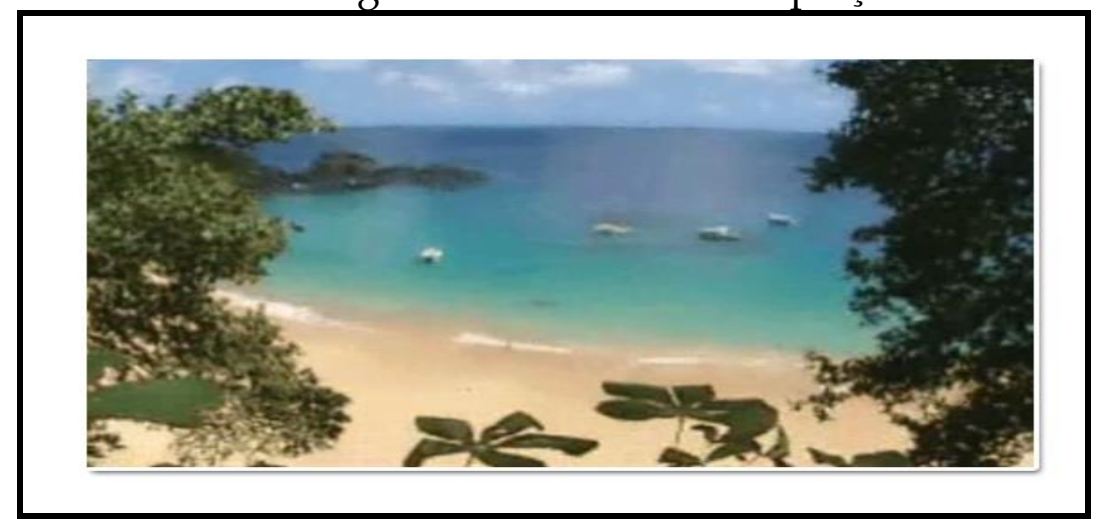


O conceito esplendor também é a base do mito tropicalidade, que evoca um conjunto de condições climáticas que caracterizam Pernambuco e favorecem a acolhida de turistas o ano todo, especialmente nas festas carnavalescas. Denominamos o signo presente nesta cadeia de estival, pois remete ao ambiente de calor intenso, com mar e coqueiros aprazíveis. $\mathrm{Na}$ Fig. 9, com o nascer do sol e as silhuetas do Morro do Pico em Fernando de Noronha ao fundo, há um conjunto de condições climáticas (calor, sol, vento) que caracterizam Pernambuco e que favorece ao estado receber turistas o ano inteiro, especialmente nas festas carnavalescas.

Figura 9 - O mito tropicalidade

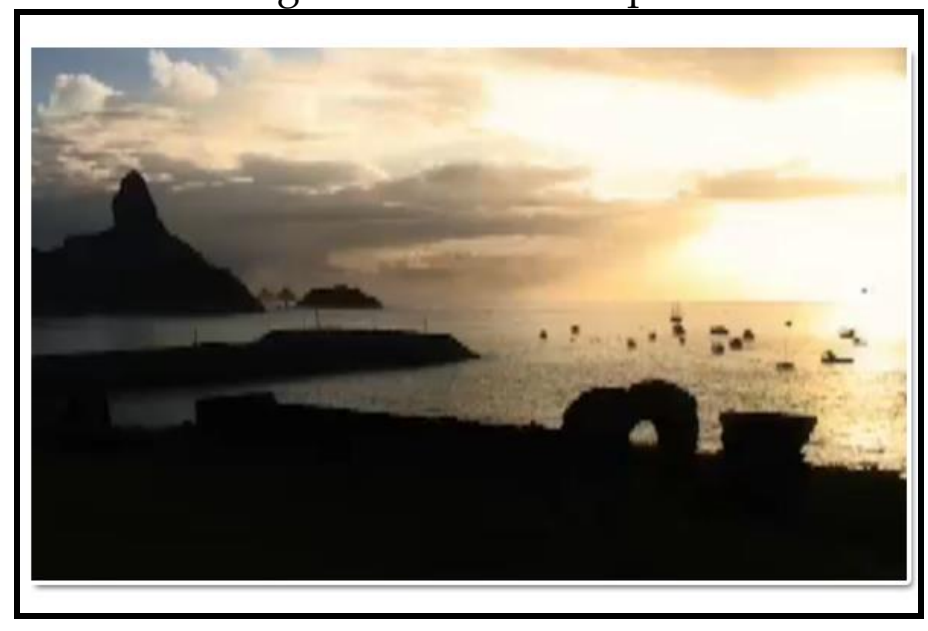

O mito diversificado tem base na abundância de possibilidades para se gozar os prazeres dos dias de Carnaval em Pernambuco, seja por meio dos vários carnavais do estado, seja por meio do descanso oportunizado pelos ambientes naturais. Está sentado no conceito melhor dos mundos, que se refere à vocação do estado de propiciar tanto uma rica variedade cultural, quanto um litoral aprazível, e no signo solução, em que Pernambuco, como destino turístico, é apresentado como resposta ao impasse entre ter que se optar entre o carnaval e a praia. Na Fig. 10, um casal que discute o destino da viagem de férias (ele deseja praia, e ela, festa carnavalesca) entra numa sala e uma porta de vidro se fecha com a inscrição Agência de Turismo, cujos serviços, bem como seu agente de turismo, despontam como a solução para o conflito do casal. 
Figura 10 - O mito diversificado

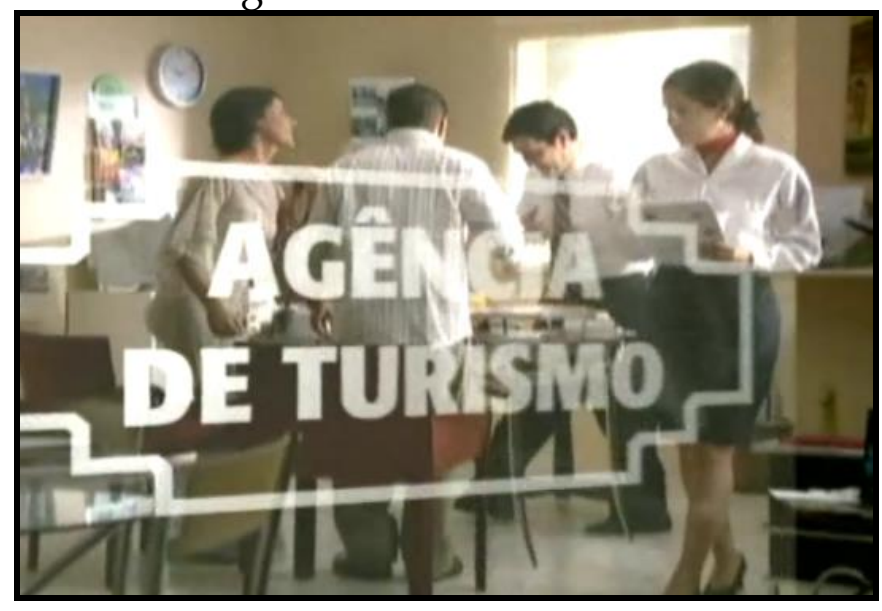

O mito encantamento refere-se ao torpor do folião-turista advindo do prazer da descoberta das variadas manifestações do Carnaval de Pernambuco. Está baseado em dois conceitos: revelação, que se reporta aos diversos elementos ou do Carnaval ou da natureza de Pernambuco, apresentados ao folião-turista, causando-lhe espanto, por serem estranhos ou desconhecidos; e deslumbramento, que se refere ao embevecimento advindo da descoberta das manifestações culturais e ambientes naturais que eram ignorados. Ambos conceitos relacionam-se ao signo surpresa, que remete à excitação da descoberta. Por estarem baseadas num mesmo signo, estas relações podem ser exemplificadas em por meio de uma mesma imagem. Na Fig. 11, o turista mostra-se fascinado com a beleza da paisagem natural - vista da beira-mar da cidade de Olinda e seus coqueiros, a partir do sítio histórico da cidade.

Figura 11 - O mito encantamento

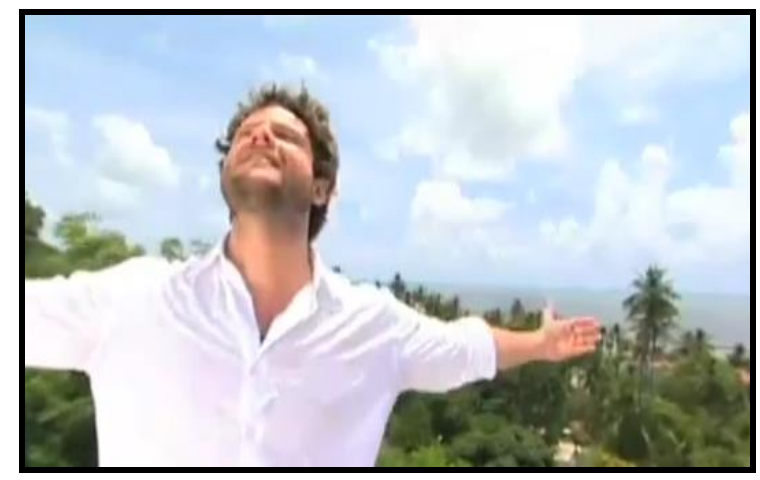

O mito erotismo alude à sedução e ao apelo sexual advindos, que se revelam nas danças, em olhares e gestos corporais. Está baseado no conceito sensualidade, que se refere ao comportamento libidinoso que convida ao sexo, por meio de dois signos: insinuação e surpresa. 
Na Fig. 12A, o folião-turista, pulando em meio a um grupo de caiporas, levanta o saco de estopa que cobre uma bela jovem, olha surpreso e a abraça. Aqui, o signo surpresa, já descrito quando da apresentação do mito encantamento, remete à excitação da descoberta da moça sob a fantasia.

O signo insinuação, por sua vez, se refere aos jogos de olhares e gestos que elaboram o convite à aproximação dos pares com a intenção de obter intimidade. Na Fig. 12B, uma bela mulher é focalizada enquanto dança para a câmera, como se estivesse olhando para alguém.

Em ambos os casos, a beleza da mulher nativa mostra-se como um convite ao desfrute, colocando-a no status de mais um dos elementos da folia, ou belezas naturais do estado, a ser ofertado e usufruído.

Figura 12 - O mito erotismo

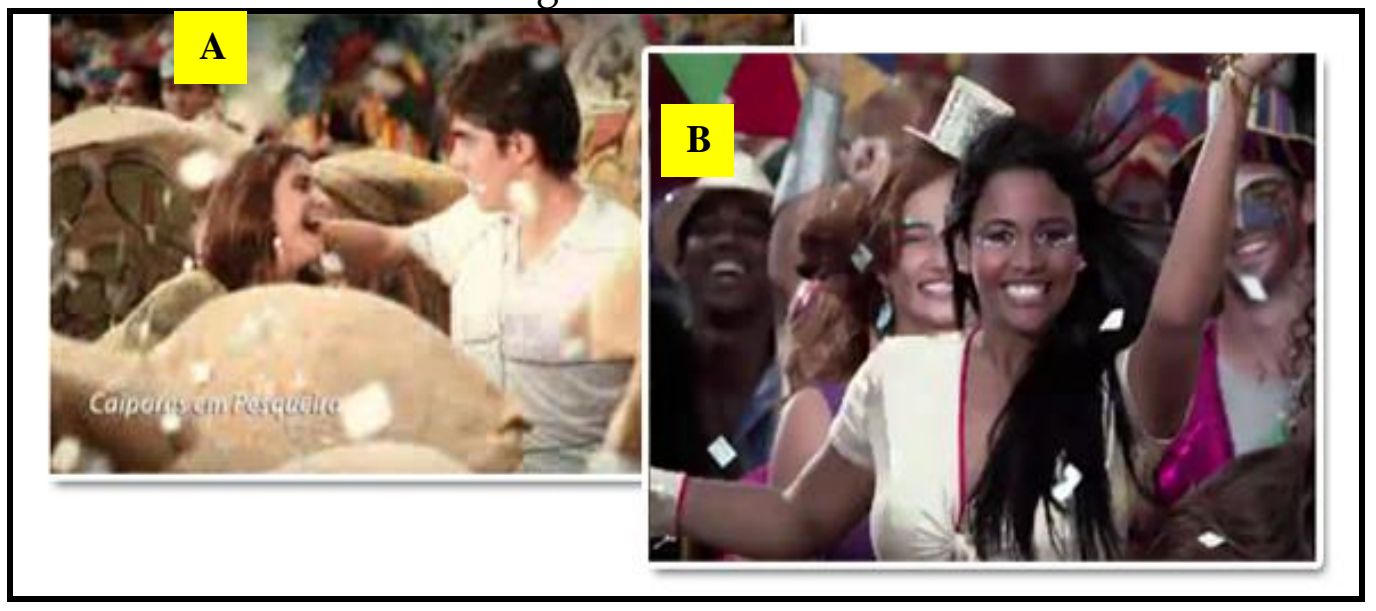

Por fim, o mito tradição diz respeito à valorização dos elementos culturais que construíram a história do Carnaval pernambucano e mantêm seu vigor como manifestação cultural. Este mito assenta-se no conceito orgulho, que se refere ao reconhecimento dos hábitos, lugares, expressões e artefatos que evocam o sentido de "pernambucanidade", sentimento de defesa e exaltação por esses elementos. Três são os signos aqui relacionados: bucolismo, que se refere ao estado de contemplação carregado pelas lembranças de outros Carnavais e o desejo de revivê-las; imponência, que remete à grandiosidade das expressões culturais, gigantismo das alegorias, dos calungas e dos estandartes; e localidade, que evoca a singularidade do Carnaval pernambucano. Apesar desta variedade, a Fig. 13 pode demonstrar todos esses aspectos. A flâmula do Bloco da Saudade, ricamente ornamentada com ramos dourados e ressaltando o ano de fundação do bloco, é sintomático da imponência descrita e revela uma tradição tipicamente pernambucana, associada a carnavais do passado. 
Figura 13 - O mito tradição

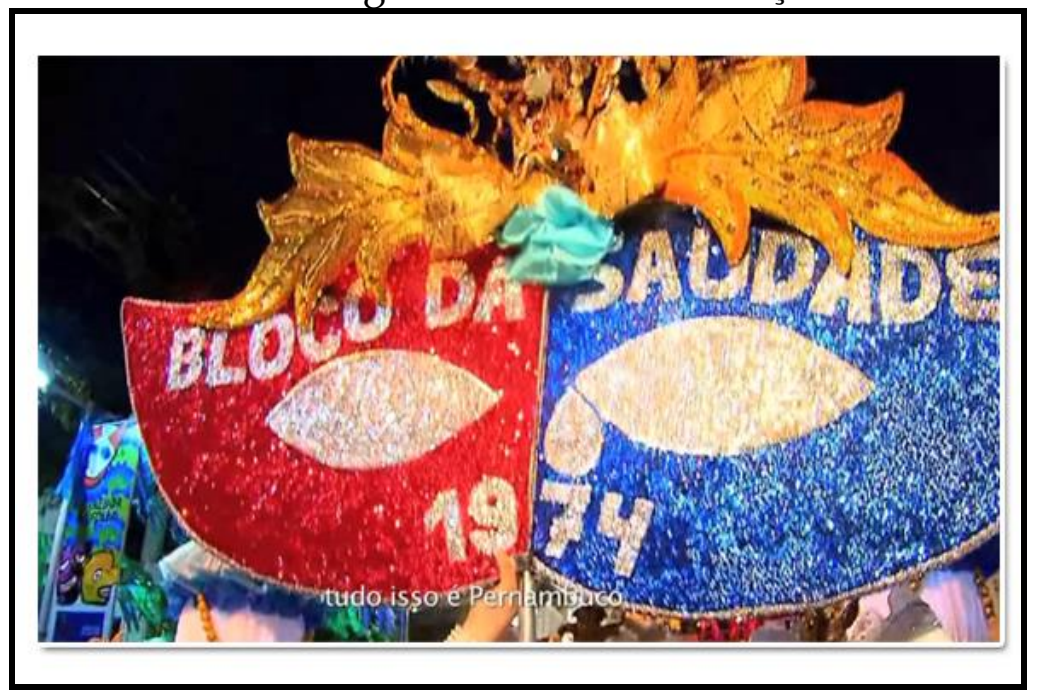

\section{“O Carnaval de Pernambuco é mais pra..." quem?}

Após analisarmos dos processos de significação de cada um dos mitos, bem como as relações entre eles, entendemos que esses elementos apontam para a configuração de uma metanarrativa, que nomeamos narrativa das trocas. Esse nome deve-se ao fato de o festejo ser representado pelo Governo do Estado de Pernambuco como um produto desenvolvido e divulgado no intuito de atrair e satisfazer o turista, tecendo um discurso em que os signos da cultura popular e o próprio Carnaval de rua convertem-se num artefato destinado à mercantilização.

No entanto, toda troca pressupõe ofertantes e demandantes. Uma vez que estudo dedica-se às peças publicitárias, observamos que, embora o turista figure como ponto central das produções, essas peças são veiculadas também para os próprios pernambucanos - estes representados como coadjuvantes de um espetáculo desenvolvido para o outro, o "de fora". Assim, resta aos pernambucanos identificar-se com signos que remetem, mais que à hospitalidade, à subserviência. Esse discurso publicitário cumpre, pois, duas funções, na medida em que essa troca possui dois beneficiários (o turista e o nativo): atrair o indivíduo "de fora" e educar o nativo para a servilidade.

Essa reflexão inicial é o ponto de partida para discutirmos a pergunta de pesquisa proposta: Como o Governo do Estado de Pernambuco mercadoriza o Carnaval pernambucano em suas peças publicitárias? Com base nesses achados, e em consonância com o caráter indutivo desta investigação, identificamos na abordagem pós-colonialista um aporte teórico para a essa discussão. O pós-colonialismo caracteriza-se por uma reflexão sobre o legado do colonialismo em sociedades periféricas e pela tentativa de ruptura com a tendência etnocêntrica de se representar o outro à luz da visão de si (ROSA; ALCADIPANI, 2013). Essas abordagens 
ganham força à medida que o conceito de "Terceiro Mundo" cai em desuso, quando se descobre não se tratar de um bloco homogêneo, mas de unidades cujas diferenças reivindicam para si e busca integrar-se ao capitalismo global a partir dessa diferença (PRYSTHOM, 2010). Conceitos como diferença, alteridade, estereótipo, subalternidade e hibridismo integram os estudos pós-coloniais. O pensamento pós-colonial propõe, então, compreender a partir de quais olhares os significados inerentes a determinadas culturas são construídos, bem como deslocar o ponto de partida desse olhar, para as regiões marginais (ROSA; ALCADIPANI, 2013; FILGUEIRAS, 2012). O uso da abordagem pós-colonial alinha-se à semiologia barthesiana, na medida em que a primeira busca questionar a imposição do olhar oriundo da alteridade, e mesmo deslocar esse olhar na construção identitária, e a segunda possibilita desconstruir narrativas profundamente naturalizadas.

No presente estudo, observamos a demarcação de dois locais: o Estado de Pernambuco e o exterior do Estado, de onde provêm os turistas. Nessa relação, o Estado figura como o ofertante de um serviço (o Carnaval), buscando moldá-lo aos anseios e às preferências do turista, destinatário dos serviços ofertados. O Estado, cuja voz manifesta-se nas peças publicitárias, mostra-se provedor da infraestrutura, mas reserva (e mesmo impõe) ao povo pernambucano, o papel de ofertante do serviço: assim, o povo, que deveria desfrutar as festividades carnavalescas, é responsável por transformá-la num espetáculo digno de apreciação pela alteridade. Isso configura uma estrutura de marketing, na medida em que insere uma manifestação popular numa lógica de mercado. No entanto, a identidade desse Carnaval, e por extensão, de todo o Estado como destino turístico, mostra-se, em nossos achados, construída a partir do olhar do turista, único beneficiário de tais "serviços", já que o nativo torna-se, à sua revelia, também ofertante.

De acordo com a perspectiva dos Estudos Culturais, toda identidade constrói-se de forma relacional, necessitando de um "outro" para demarcar o "eu" (WOODWARD, 2009). Esse processo ocorre nos sistemas de representação, nos quais as identidades adquirem sentido (SILVA, 2000). A representação conecta os significados e a linguagem à cultura, e esta estabelece as fronteiras e a diferença (HALL, 1997). Nesses sistemas de representação, por sua vez, a demarcação de identidade e diferença não ocorre isenta de valoração: a relação eu/outro pressupõe uma hierarquização, na qual um torna-se desejável, em detrimento do outro. Nesse processo de demarcação de diferenças, certas identidades, consideradas positivas, podem ser tão desejáveis ao ponto de se naturalizar, tornando-se livres de questionamento, ao passo que seu oposto torna-se uma anormalidade (TAVARES; ALVES, 2008).

Nesse sentido, Barbalho (2004) chama atenção para o poder do discurso midiático na construção da ideia de Nordeste, uma vez que este inverte a relação de poder eu/outro, tornando o outro responsável pelo 
olhar sobre o eu e pela imposição da sua identidade, o que se deve ao fato de os primeiros discursos midiáticos no Brasil, e consequentemente as primeiras representações do Nordeste, terem surgido a partir de um olhar oriundo do eixo Sul-Sudeste, portanto do outro. Trata-se, portanto, de uma construção arbitrária, na qual os signos sociais e culturais são representados, numa marginalização intencional das formas de alteridade (BHABHA, 2007).

Segundo Hall (2006), a própria cultura nacional é um discurso, na qual símbolos e representações são evocados para a construção de identidades tanto locais quanto individuais. Dentre as estratégias discursivas por ele apontadas, encontram-se as tradições inventadas, que estabelecem um vínculo artificial de continuidade com o passado, por meio da repetição de práticas rituais ou simbólicas (HOBSBAWM, 2012). É dessa forma que o Carnaval de rua, ao se converter num espetáculo digno de mercantilização e de atração de investimentos turísticos, rompe com o seu caráter libertário e agressivo do passado, quando tais manifestações eram exclusivas das classes menos abastadas, impedidas pelas autoridades de participarem das comemorações, restritas à aristocracia. Nesse sentido, o Carnaval popular, o Carnaval de rua, onde não há restrição nem distinção, constitui uma tradição inventada, na medida em que não só fugiu ao controle das autoridades no sentido de conter tais manifestações, como foi absorvido e incorporado ao imaginário popular e gerido como um símbolo identitário da nossa cultura.

Outro aspecto importante na construção de uma narrativa da cultura nacional, segundo Hall (2006), é o mito fundacional, um conjunto de histórias que caracterizam o surgimento das nações, bem como seu povo, num tempo mítico. No caso de Pernambuco, a repercussão da dramaturgia de Ariano Suassuna, bem como de seu Movimento Armorial, acolhidos pelo intuito de se construir uma identidade brasileira quando do regime militar (BARBALHO, 2004), estão intimamente ligados ao mito fundacional do Estado. No entanto, se por um lado reivindica-se um mito fundador, um símbolo identitário com o qual se identificar, por outro, esses elementos são reificados, convertendo-se em signos do consumo, não exigindo do consumidor qualquer entendimento ou comprometimento com aquela manifestação cultural.

Mas que olhar é esse? Qual a representação de Pernambuco construída com base nessa alteridade? Aqui, é válido ressaltar que essas construções também atendem a interesses de agentes diversos. Assim, como resultado de um trabalho político, a imagem do Nordeste atrasado, flagelado, aos poucos, e com o apoio da mídia, dá lugar ao Nordeste paradisíaco, emergente, promissor em relação aos investimentos "de fora" (Costa, 1998). Isso reforça uma posição colonialista na qual prevalece uma lógica de mercado na construção da identidade local: a região é, ao mesmo tempo, paradisíaca e atrasada, estando, portanto, susceptível à "colaboração" do agente de fora, investidor ou turista, que irá usufrui-la, 
proporcionando, em contrapartida, subsídios para seu "desenvolvimento". O que seria isso senão uma colonização dentro de outra colonização? Nesse estágio do capitalismo, não mais caberia um Nordeste-flagelo completamente destoante do fluxo do capital no espaço nacional (COSTA, 1998).

Ressaltamos que, na perspectiva ora adotada, as identidades correspondem a construções discursivas. Nesse sentido, essa representação arbitrariamente construída a partir do olhar do outro resulta em distorções como o estereótipo, que constitui uma estratégia discursiva de fixidez da alteridade (BHABHA, 2007). No presente estudo, um conjunto de representações tais como praias paradisíacas, ausência de censura e limites, hedonismo e subserviência do nativo constitui essa identidade local, ainda que sob um olhar exterior. Dessa maneira, o Carnaval de Pernambuco, um festejo do povo e para o povo, converte-se num produto em que o povo (em tese, beneficiário dos festejos, aquele que desfruta os prazeres do festejo) converte-se num staff que elabora a festa para o usufruto do outro, "de fora", no intuito de servi-lo. Nessas representações, o turista figura, portanto, como o centro das atenções não só do Governo do Estado, mas também dos seus cidadãos.

As práticas de marketing e comunicação apresentam uma posição central na produção e reprodução de projetos coloniais, assim como os discursos mercadológicos relacionados à promoção de destinos turísticos, que muitas vezes perpetuam um imaginário e uma ideologia coloniais (JACK, 2008). Esse discurso colonial tem no estereótipo sua principal estratégia e, ao mesmo tempo, gera nos sujeitos um processo de reconhecimento por imagens alienantes (BHABHA, 2007). Assim, o pernambucano se identifica com um "pernambucano" construído à luz de culturas hegemônicas (neste caso, o eixo Sul-Sudeste) e, não apenas se vê sob essas lentes, como perpetua esses olhar e legitima uma visão de si aos olhos do "colonizador". Do ponto de vista midiático, e assumindo a mídia como uma importante fonte de representações com as quais nos identificamos, somos uma colônia dentro de outra colônia.

\section{"As muitas caras de um Carnaval 'de todos"”}

A análise das peças publicitárias desenvolvidas para promover o Carnaval do Estado de Pernambuco aponta para a mercadorização desta manifestação cultural por meio de um processo de reificação no qual a mesma converte-se em um serviço, passível de ser gerido, portanto, sob uma lógica de mercado. No entanto, o agente que impõe essa lógica é o próprio Governo do Estado, a quem cabe a função de gerir o espaço e o patrimônio público. Entre esse patrimônio, inclui-se o imaterial, o qual deve ser gerido de modo a preservá-lo e transmiti-lo às gerações futuras. No entanto, o que observamos é a conversão desses símbolos identitários em espetáculos mercantilizados, cujo propósito, em vez de ser a 
preservação desse patrimônio, é o retorno financeiro oriundo dessas festividades.

Por outro lado, há um discurso desenvolvimentista que embasa tais ações. Para o Governo do Estado, ofertar esse patrimônio imaterial sob a forma de espetáculos atrai investimentos "de fora", bem como projeta a imagem do Estado como destino turístico, não só no período carnavalesco. Nesse sentido, a ideia de desenvolvimento é atrelada apenas à dimensão econômica, e essa dimensão justifica a mercantilização desses símbolos.

Assim, o Pernambuco paradisíaco, bem como o Carnaval "multicultural", é uma estratégia discursiva, uma tradição inventada, da qual a Administração Pública se apropria, e promove, no intuito de inserir o Estado no fluxo da economia global. Isso nos reaproxima das práticas coloniais, nas quais a ideia de desenvolvimento é praticamente restrita ao econômico, e os símbolos identitários do local encontram-se à disposição para o usufruto do colonizador sem qualquer compromisso com a preservação desses símbolos.

A Administração Pública, ao assumir essa lógica mercantil, não só reifica o patrimônio imaterial, como também reforça os estereótipos construídos pela alteridade e propaga, portanto, uma visão distorcida de si mesmo com a qual os próprios pernambucanos tendem a se identificar, dado o alcance da programação televisiva. Por sua vez, o nativo se identifica não só com esse olhar distorcido sobre seu Estado e suas manifestações culturais, como também com a servilidade que se espera desse povo, para que o "desenvolvimento" se concretize.

Por fim, o presente estudo aponta para possíveis desdobramentos, tanto no campo dos Estudos Organizacionais, envolvendo inclusive a Administração Pública e a gestão do patrimônio imaterial; como no campo da Comunicação e mesmo em abordagens críticas de marketing, as quais já se beneficiam das abordagens pós-coloniais, ainda que no Brasil esse campo seja ainda incipiente.

\section{Referências}

ARAÚJO, R. C. B. "Carnaval do Recife: a alegria guerreira". Estudos Avançados, São Paulo, v. 11, n 29, p. 203-216, 1997.

BARBALHO, A. "Estado, mídia e identidade: políticas de cultura no Nordeste contemporâneo". Alceu, v. 4, nº 8, p. 156-167, 2004.

BARKER, C. Cultural Studies: Theory and practice. 4 Ed. UK, Sage, 2012.

BARTHES, R. Elementos de Semiologia. 16. ed. São Paulo, Cultrix, 2006.

BARTHES, R. Aula. 15. ed. São Paulo, Cultrix, 2007.

BARTHES, R. Mitologias. 5. ed. Rio De Janeiro, DIFEL, 2010. 
BHABHA, H. O lugar da cultura. Belo Horizonte, UFMG, 2007.

BRASIL. Ministério do Turismo. Carnaval de Salvador. Disponível em: http:/ / www.eventos.turismo.gov.br/eventos/eventos/detalhe/carnaval_ salvador2012.html. Acesso em: 28 jul. 2012.

CARVALHO, N. Prefácio interessantíssimo. In: NOVA, J. V. Panorama do Folião: o carnaval de Pernambuco na voz dos blocos líricos. Recife: Fundação de Cultura da Cidade do Recife, 2007.

CHANDLER, D. Semiotics for Beginners. (1999). Disponível em: http://www.domini cpetrillo.com/ed/semiotics_for_beginners.pdf. Acesso em: 10 abr 2012.

COSTA, L. F. A. "Revisitando a questão do Nordeste: representações de uma região-problema". Políticas Públicas e Sociedade, vol. 1, n 1, pp. 8397, 1998.

CRESWELL, J. W. Projeto de pesquisa: métodos qualitativo, quantitativo e misto. 3. ed. Porto Alegre, Artes Médicas, 2010.

DANESI, M. "Semiotics of media and culture". In: COBLEY, P. (Ed.). The Routledge Companion to Semiotics. London, Routledge, 2010.

DENZIN, N. K.; LINCOLN, Y. S. (Org). O planejamento da pesquisa qualitativa: teorias e abordagens. Porto Alegre, Artmed, 2006.

DINIZ, A. Almanaque do carnaval: a história do carnaval, o que ouvir, o que ler, onde curtir. Rio de Janeiro, Jorge Zahar Ed, 2008.

DUMAZEDIER, J. A revolução cultural do tempo livre. São Paulo: Studio Nobel - SESC, 1994.

FARIAS, E. "Economia e cultura no circuito das festas populares brasileiras". Sociedade e Estado, Brasília, v. 20, n. 3, p. 647-688, set./dez, 2005.

FERREIRA, F. O Livro de Ouro do Carnaval brasileiro. Rio de Janeiro, Ediouro, 2004.

FILGUEIRAS, F. B. "Guerreiro Ramos, a redução sociológica e o imaginário pós-colonial”. Caderno CRH, v. 25, n. 65, p. 347-363, 2012.

FIRAT, A. F.; DHOLAKIA, N. Consuming people: from political economy to theaters of consumption. London, Routledge, 2003. 
FITCHETT, J. A. Book Review: Inside Marketing: Practices, Ideologies, Devices. Oxford University Press, 2010. Version of 2012. Disponível em: http:/ / oss.sagepub.com/content/33/3/447, acesso em 21 jun. 2013.

FUNDARPE. Disponível em: http://www.nacaocultural.pe.gov.br. Acesso em: 14 jul. 2011.

JACK, G. "Postcolonialism and marketing”, In Tadajewsky, M. Brownlie, D. (Orgs.), Critical Marketing: Contemporary Issues in Marketing. United Kingdom: John Wiley \& Sons, 2008, p. 363-383.

HALL, S. "The work of representation". In: HALL, S. (org.), Cultural representation and cultural signifying practices. London, Sage, 1997.

HALL, S. A identidade cultural na pós-modernidade. 11.ed. Rio de Janeiro, DP\&A, 2006.

HÉNAULT, A. História concisa da semiótica; tradução Marcos Marcionilo. São Paulo, Parábola Editorial, 2006.

HOBSBAWN, E. "Introdução: A Invenção das Tradições", In: HOBSBAWM, E.; RANGER, T. (orgs.), A Invenção das Tradições. 2.ed. São Paulo, Paz e Terra, 2012.

IG ECONOMIA. Carnaval movimenta $\mathbf{R} \$ 2,7$ bilhões e gera mais renda que muitas empresas. 20/02/2012. Disponível em: http:/ /economia.ig.com.br/empresas /comercio servicos/carnavalmovimenta-r-27-bilhoes-e-gera-mais-renda-que-muitas-emp/ n15976 42537130.html. Acesso em: 25 jul. 2012.

LEÃO, A. L. M. S. et al. “Élan Vital: O 'Eu do Momento' no Caráter Libertário da Criação Publicitária", Revista Organizações em Contexto online, São Bernardo do Campo, Ano 7, n. 14, 2011.

LEÃO, A. L. M. S.; MELLO, S. C. B.; VIEIRA, R. S. G. “O papel da teoria no método de pesquisa em Administração". Organizações em Contexto. Ano 5, n. 10, 2009.

LOIZOS, P. "Vídeos, filme e fotografia como documento de pesquisa". In: Pesquisa qualitativa com texto, imagem e som: um manual prático. Petrópolis, Vozes, 2002.

LOSSIO, R.; PEREIRA, C. "História e estórias do carnaval em Pernambuco". Folclore, Recife, março, p. 314-338, 2008. 
MEDEIROS, B. T. F. “O Estado da Arte dos Estudos sobre Patrimônio Cultural Imaterial no Nordeste". In: ABANNE- Reunião de Antropólogos Norte-Nordeste, 8, 2003. Anais... ABANNE, 2003.

MERQUIOR, J. G. Saudades do carnaval: introdução à crise da cultura. Rio de Janeiro, Forense, 1972.

MONTES, M. L. “Entre o arcaico e o pós-moderno: heranças barrocas e a cultura da festa na construção da identidade brasileira". In: Sexta-feira, vol. 2, São Paulo, Editora 34, 1998.

OSWALD, L. R.; MICK, D. G. "The semiotic paradigm on meaning in the marketplace". In: BELK, R. W. Handbook of Qualitative Research Methods in Marketing. Cheltenham (UK), Edward Elgar Pub. 2006.

PAIVA JUNIOR, F. G.; LEÃO, A. L. M. S.; MELLO, S. C. B. “Validade e confiabilidade na pesquisa qualitativa em Administração". Revista de Ciências da Administração, vol. 13, nº 31, 2011.

PERNAMBUCO (Estado) (2011a) Disponível em: http://www2 .pe.gov.br/web/ portal-pe/exibir-

noticia?groupId=199430\&articleId=589760\&template $\mathrm{Id}=206875$. Acesso em: 22 jul.de 2011.

PERNAMBUCO (Estado) (2011b) Economia do carnaval de Pernambuco tem crescimento de 54\%, 18 de março de 2011. Portais do Governo de Pernambuco. Disponível em: http:/ / www2.setur.pe.gov.br/web/guest;jsessionid=919146991C3EB2749 9D07 2C63BD6 8CF8. Acesso em: 19 jan. 2012.

PERNAMBUCO (Estado) (2012a) Mais carnaval no interior e com artistas da terra. 18 de janeiro de 2012. Disponível em: http:/ /www.diariodepernambuco.com.br/2012/01/18/ vidaurbana9_0.asp. Acesso em: 20 jan. 2012.

PERNAMBUCO (Estado). (2012b) Foco Estratégico - Turismo. Disponível em: www.pe.gov.br/governo/focos-estrategicos/turismo/. Acesso em: 07 ago. 2012.

PRYSTHON, A. “Histórias da teoria: os estudos culturais e as teorias póscoloniais na América Latina". Interin, vol. 9, n. 1, 2010.

RAMOS, R. J. "Roland Barthes: a semiologia da dialética". Revista Conexão - Comunicação e Cultura, UCS, Caxias do Sul, v. 7, n. 13, p. 159$169,2008$. 
RAMOS, R. J. "Roland Barthes: semiologia, mídia e fait drivers". Revista FAMECOS, Porto Alegre, n. 14, 2001.

RIOTUR. Mais de 4 milhões curtem Carnaval. 22/02/2012. Rio Guia Oficial. Rio de Janeiro. Disponível em: http:/ / www.rioguiaoficial.com.br/noticias/mais-de-4-milh-es-curtemcarnaval-0. Acesso em: 25 de jul. 2012.

ROCHA, M. E. M. “Do 'mito' ao 'simulacro': a crítica da mídia, de Barthes a Baudrillard”. Revista Galáxia, São Paulo, n. 10, p. 117-128, 2005.

ROSA, A. R.; ALCADIPANI, R. "A terceira margem do rio dos estudos críticos sobre administração e organizações no Brasil: (re)pensando a crítica a partir do pós-colonialismo". RAM, Revista de Administração da Mackenzie, v. 14, n. 6, p. 185-215, 2013.

SEBE, J. C. Carnaval, Carnavais. São Paulo: Ática, 1986.

SETUR. Secretaria de Turismo do Estado de Pernambuco. Carnaval gerou R\$ 773,6 milhões para a economia de Pernambuco. Disponível em: <http://www2.setur.pe.gov.br/web/setur/exibir-

noticia?groupId=21782\&articleId= 1754765 \&templateId=28657>. Acesso em: 04 jul. 2012.

SILVA, M. R. P. "Lição crítica: Roland Barthes e a semiologia do impasse". ALEA Estudos Neolatinos, Rio de Janeiro, vol. 7, nº 1, p. 65-78, 2005.

SILVA, T. T. “A produção social da identidade e da diferença”, In: SILVA, T. T. (org.). Identidade e diferença. Petrópolis, RJ, Vozes, 2009.

SIMÕES, D. “Rastreando as teorias semióticas: um projeto de estratégias técnico-pedagógicas". Caderno Seminal Digital, Rio de Janeiro, v. 5, n. 5, 2006.

SOUZA, I. S.; LEÃO, A. L. M. S. “Dionísio Usa Chilli Beans? Análise Mitológica da publicidade da 'Marca da Pimenta'". RAC, v. 17, n. 5, art. 4, p. 574-597, 2013.

TAVARES, A.; ALVES, L. K. (2008), “Representação da personagem Ennis Del Mar no filme O Segredo de Brokeback Mountain: identidade e heteronormatividade". Revista Travessias. Unioeste. v. 2, n. 3, 2008.

TENDÊNCIAS E MERCADO. A economia do carnaval de Pernambuco tem crescimento de 54\%. 2011. Disponível em: http:/ / www.tendenciasemercado. com.br/negocios/pe-economia-docarnaval-tem-crescimento-de-54/. Acesso em: 20 jul. 2011. 
WOODWARD, K. “Identidade e diferença: uma introdução teórica e conceitual". In: SILVA, T. T. (org.). Identidade e diferença. Petrópolis, RJ, Vozes, 2009.

\footnotetext{
' O presente trabalho foi realizado com o apoio da Fundação de Amparo à Ciência e Tecnologia do Estado de Pernambuco.
} 